\title{
The Effect of Lockdown Due to the COVID-19 Pandemic on Digital Eye Strain Symptoms Among the General Population: A Cross-Sectional Study
}

Mohammad Abusamak ( $\rightarrow$ mabusamak@bau.edu.jo)

Al Balqa Applied Univeristy Faculty of Medicine https://orcid.org/0000-0002-7832-1184

Hatim Jaber

Al Balqa Applied University Faculty of Medicine

Hamzeh Mohammad Alrawashdeh

Amman Eye Clinic

\section{Research Article}

Keywords: digital eye strain, general population, COVID-19, symptoms

Posted Date: May 28th, 2021

DOI: https://doi.org/10.21203/rs.3.rs-500071/v1

License: (c) (i) This work is licensed under a Creative Commons Attribution 4.0 International License. Read Full License 


\section{Abstract}

Purpose: the study examined the effect of prolonged lockdown on the development and increased severity of digital eye strain (DES) symptoms among the general population.

Methods: An online survey was conducted in March 2020 on social media platforms in Jordan. The questionnaire consisted of questions related to demographic characteristics, past medical and ocular history, frequency of using digital devices before and during lockdown, and the emergence and severity of DES symptoms.

Results: Data from 1,460 responders were analyzed. About half of the respondents were between $30-49$ years, $28.4 \%$ were retired, $21 \%$ had chronic systemic illness, and $23 \%$ reported chronic eye problems. A rise in the use of digital devices during lockdown was reported by 957 participants, with 33\% of them used digital devices more than 4 hours a day. The most common symptoms before and during lockdown were neck and shoulder pain, which revealed the most significant association ( $\left.X^{2} 201.61, p 0.000\right)$. Female gender, existence of chronic eye problems and systemic diseases, and duration of using digital devices were found to be statistically significant factors associated with increasing severity of eye symptoms during lockdown. Regarding developing new eye complaints during the lockdown, only taking regular breaks was not significant $(p$ 0.336). People with chronic eye problems and increased time using devices during lockdown developed new eye complaints three times more than before the lockdown and males were two times more likely than females to have more severe eye symptoms.

Conclusion: The majority of the population developed new DES symptoms due to the lockdown. Public awareness of healthy practices and ergonomic use of digital devices is recommended.

\section{Introduction}

Digital eye strain (DES), also known as computer vision syndrome (CVS) or visual fatigue, is a cluster of ocular, visionrelated, and musculoskeletal symptoms induced by the repeated use of digital devices (also known as video display terminals [VDTs]). Any electronic hardware that is used daily is referred to as a digital device and may include a multitude of devices such as cell phones, smart wristwatches, desktop computers, tablets, virtual reality viewers, 3D displays, and e-readers, among others. Eye pain, dry eyes, headaches, blurred vision, and neck and shoulder pain are the most common symptoms associated with DES. ${ }^{1,2}$ Owing to the massive shift to the use of digital devices globally in the last few decades, DES has become a very real and identifiable issue that affects millions of people, placing people of all ages at risk. ${ }^{1,2}$

The repeated use of digital devices for more than two continuous hours is putting the user at a great risk of developing DES due to the excessive accommodative demands. ${ }^{1,3}$ Refractive errors that are uncorrected, undercorrected, or over corrected can exaggerate the symptoms. ${ }^{4}$ Unlike printed pages, letters on digital displays are not sharply outlined, with lower letters contrast to the background, as well as the effect of glare and reflection, rendering viewing more difficult. ${ }^{5}$ Furthermore, given the various distances and angles of viewing, the eye movement and focusing demands are substantially higher than those needed when writing on or reading from paper. Muscle spasms and pain can occur as a result of poor posture when using digital screens, especially in the neck, shoulders, and back. This is particularly evident in people with refractive errors and substandard viewing glasses or contact lenses, which cause them to tilt their heads or lean on the screen in awkward ways in order to see more clearly. ${ }^{5}$ The majority of people develop DES when the visual demands of performing tasks overcome their visual capability to do so comfortably. ${ }^{6}$ 
Digital eye strain management is not simple. It requires the treatment of prior eye problems such as ocular surface disease and the optimal treatment of current eye symptoms by taking frequent breaks and adjusting the way video digital screens are presented by following healthy positions of posture. ${ }^{7-10}$ In addition, the correction of refractive errors, especially spherical hyperopia and astigmatism, is associated with better outcomes. ${ }^{4}$

The spread of COVID-19 was rather troubling to health authorities and the public at large in early February 2020. Several countries agreed to suspend foreign and domestic travel and enforce curfews on their citizens for several weeks to slow the spread of the pandemic. As a result of this situation, people were forced to rely on the Internet and digital devices as their primary means of communication. The authors noticed that the prolonged use of digital devices among students and academics, in particular, seemed to be leading to an increase in eye symptoms, which sparked the idea for this study. As a result, the study aims to examine how lockdown has affected DES symptoms in the general population. An association was expected between occupation, age, gender, and the prevalence of chronic systemic and ocular disease, which would affect the emergence of new symptoms and increase the severity of DES symptoms.

\section{Methods}

Between March 26 and April 29, 2020, a cross-sectional study was conducted. It consisted of a self-administered online survey conducted across social media platforms. Non-probability sampling methods were used for the online survey, such as convenience sampling, volunteer opt-in panels, and snowball sampling. In general, a sample size of around $10 \%$ of the population, but not exceeding 1,000 participants, was considered appropriate. The total population of Jordan was estimated to be 10.2 million in 2020, with about 1.3 million Syrian refugees residing in the country. As a result, a sample size of 1,400 could be considered representative. Demographic segmentation and social networks were used to target respondents in medical schools and social groups along with teachers and university professors and ensure a high response rate. The survey link was shared on Facebook and other social media platforms where the target audience visits regularly and distributed the survey via email, Messenger, and WhatsApp to reach the target audience.

The questionnaire (Appendix) was published in Arabic with an introduction that emphasized the purpose and objectives of this study, along with a consent requirement. Screening questions were included in the survey to ensure that the expected target respondents were reached. The questionnaire included single and multiple choice closedended questions about demographics, chronic and ocular disorders, and the amount of time people spent using digital devices. There were also questions about DES symptoms such as blurring of vision at a distance and near distance, burning sensation, redness, lacrimation, heaviness of eyelids, eye discomfort (foreign body sensation), double vision, eye pain, headaches, photophobia, and neck pain. The authors used the 3-point Likert scale (not present, sometimes, and always) to assess the consistency and intensity of vision problems for ease of use by the general public. The authors used two timeframes to account for the time spent using digital devices: baseline time spent using digital devices daily and the number of additional hours per day.

The emergence of new eye complaints and the worsening of current DES symptoms were the dependent variables in this study. A descriptive analysis was undertaken to identify the statistical scope of all variables, while a bivariate analysis was applied to test dependency between the categorical variables. Logistic regression analyses were carried out to identify the relation between the socio-demographic health characteristics and the occurrence of the two dependent variables (emergence of new eye complaints and worsening of current DES symptoms) by the top-down step method for the most complete model. 
Ethical approval was obtained from the Institutional Review Board of the Al Balqa Applied University (BAU) abiding by the tenets of the declaration of Helsinki 2008 and its amendments. The purpose of the study was clearly explained in the opening page of the survey and voluntary participation was encouraged. No personal information was obtained, and the confidentiality of the data was assured.

\section{Results}

Table 1 describes the statistical summary of the main findings of the survey. A total of 1,460 participants, close to $60 \%$ of whom were men, completed the survey. Males had an average age of $36.5[ \pm] 1.2$ years while females had an average age of $39.4[ \pm] 1.5$ years. In terms of occupation, the survey respondents were mostly retired or working at home (household), accounting for $28.4 \%$ of the total sample. Only $3 \%$ of the total sample consisted of school students. In addition, $20.9 \%$ of respondents declared they have a chronic systemic condition, and $22.9 \%$ reported having chronic vision problems. Respondents reported they spent an average of $5[ \pm] 2.6$ hours a day on digital devices before the lockdown. However, 957 respondents, which are $65 \%$ of the total sample, indicated that their daily time spent on digital devices increased during the lockdown, with the additional average time being around 4 hours per day (33\%).

The prevalence and severity of 12 symptoms were evaluated using the DES questionnaire at baseline (before) and during lockdown. The most common symptoms before lockdown were neck and shoulder pain, blurred vision at a distance, headaches, burning sensation, blurred vision of near objects, and photophobia. The most common symptoms reported were neck and shoulder pain, headaches, burning sensation, blurred vision at a distance, photophobia, blurred vision of near objects, lacrimation, and eye strain as seen in Table 2.

Furthermore, the study revealed that 242 respondents completed the three-point Likert scale (not present, sometimes, and always) examining the number of symptoms before and during lockdown. This was an important finding because it enabled us to examine the associations between the symptoms reported by respondents $(n=242)$ before and during lockdown. A statistically significant association was found between all symptoms that increased during lockdown ( $p$ 0.000), where neck and shoulder pain has the highest association $\left(X^{2} 201.61, p 0.000\right)$ while the least association was found with excessive tearing $\left(X^{2} 116.91, p 0.00\right)$ as shown in table 3.

In Table 4, the results of the logistic regression can be seen. We found that all reported factors associated with new eye complaints during the lockdown were statistical significant except for taking regular breaks $(p 0.336)$. Analysing the variables that played a role in increasing the severity of eye symptoms during lockdown, the authors found that female sex, existence of chronic eye problems and systemic diseases, and duration of using digital devices to be statistically significant as presented in Table 5.

The results of the logistic regression to study the factors associated with new eye complaints (model 1) and increased severity of current eye complaints (model 2) are reported in Table 6. Both models have a satisfactory goodness-of-fit according to the Chi-square test $(p<0.0001)$ and respectively $\mathrm{R}^{2} 9$ and $14 \%$.

The variables of chronic eye problems and increased time using digital devices during lockdown were found to be associated with the emergence of new eye complaints in model 1 in Table 6. The variable of chronic eye problems was significantly associated with having new eye complaints $(p<0.002)$. In comparing individuals with chronic eye problems to those who have not had chronic eye problems, the odds ratio shows that having new eye complaints after lockdown increased by around three times. The variable of increased time spent using digital devices during lockdown is significantly associated with the development of new eye complaints ( $p 0.000)$. Furthermore, the odds ratio of 3.56 
indicates that anyone who spent more time on digital devices had four times the risk of developing a new complaint as the person who did not spend time on them. In model 2, it was found that males developed severe eye symptoms two times more than females $(p 0.001)$. Odds ratios for the variables of chronic eye disease, increased time using digital devices during lockdown, and increased amount of time are higher than the odds ratios before lockdown, similar to model 1.

\section{Discussion}

The government of Jordan imposed a strict lockdown and curfew hours for six weeks, beginning March 18, 2020 and ending April 29, 2020 to contain the COVID-19 pandemic. This study aimed to see how homebound lockdown affected the development and severity of baseline and new digital eye strain symptoms (DES).

The data revealed that young males responded to the online survey more than females, which was consistent with consumer behavior on social media platforms during the lockdown. ${ }^{11}$ This could have increased the prevalence of eye symptoms in male subjects, particularly the new onset of DES symptoms.

Females had more severe lockdown symptoms than males in this study, which were statistically significant for most symptoms such as neck/shoulder pain, photophobia, blurred vision at distance, eye redness, heavy eyelids, and difficulty focusing on near objects, as shown in Tables 4 and 5.

Correlation between gender and musculoskeletal symptoms was explored. We found that females had more neck/shoulder pain during lockdown than before. For instance, in addition to the time spent on social media; women are helping their children in online school learning. An effective policy is needed to rationalize and to impose regular breaks women use of social media and online learning platforms. ${ }^{12}$

The majority of the survey respondents declare using digital devices more than an average of 5 hours daily. In addition, this finding is consistent with the $65 \%(n=957)$ persons that have reported an increase in their use of digital devices from which $33 \%$ of them reported 4 hours or more during the lockdown period (table 1). As people selfreported their time spent on digital devices, it could be expected that they underestimated their actual time spent on digital devices because they may not have counted internet, TV, mobile phones, or tablets. Recent studies have found

a global trend toward spending more time with digital devices, particularly among younger generations. ${ }^{13-15}$ In 2016 , Common Sense Media (CSM) reported that American parents of teenagers spend about 9 hours per day on the Internet. ${ }^{16}$ Similarly, a survey conducted by CMS in 2019 revealed that teenagers spend more than 7 hours per day on media. ${ }^{17}$ According to Reddy et al.(2013), using digital devices for more than 2 hours per day has a significant impact on DES symptoms. ${ }^{21}$ Blatter et al. (2002) also observed that increased computer use, with or without mouse use, was correlated with musculoskeletal pain and dysfunction. Moreover, they found positive associations with work-related upper limb disorders for both genders with computer use of more than 6 and 4 hours per day, respectively. ${ }^{18}$

In the current study, taking regular breaks was found to be statistically significant for blurred vision at a distance and difficulty focusing on near objects. However, this is not so for neck pain or dry eye symptoms, respectively. Logaraj et al. (2014) showed that students who took regular breaks were less likely to show symptoms of DES. ${ }^{19}$ Indeed, Lemma et al. (2020) studied the effect of taking regular breaks on the development of DES when compared to those who did not take frequent breaks. It was found that secretaries who took regular breaks were $72.1 \%$ less likely to experience digital eye strain. ${ }^{20}$ 
Jordanian schools and universities rushed to adopt online education during the lockdown, resulting in a significant shift in the digital device usage habits of educators and students. Due to the compulsory online studies and high demand for Internet, teachers, researchers and workers were among the most affected by new DES complaints during the lockdown. This is in line with the findings of several studies conducted in Middle Eastern and Asian countries. ${ }^{14,15,21}$ Contrary to the hypothesis, manual workers developed new symptoms of DES more than other occupations (OR 1.42, 95 \% C.I). The reason for this is that manual workers used digital devices for communication and online services more than they did previously. Interestingly, the lockdown resulted in an increase in the severity of symptoms reported by all respondents in occupational groups, with retirement and household having the highest odds ratio (OR 6.09, 95 \% C.I.) followed by university students (OR 5.6, 95 \% C.I.), which highlights the importance of public awareness and early management of DES in improving the education process and helping retired people improve their vision quality as seen in table 6. Furthermore, retired people and households are at greater risk for DES because they are more likely to have chronic systemic and ocular diseases that were worsened by having to use digital devices for increased hours than they were when they first started. ${ }^{12}$

This research showed that individuals with chronic eye problems are at a higher risk of developing new DES complaints and increasing the severity of their symptoms, even if they spend less time using digital. The results of Ranasinghe et al. (2012) indicated that chronic eye diseases were the greatest risk factor for DES development among Sri Lankan computer workers. ${ }^{12}$ As well, both new and severe eye symptoms were associated with the presence of chronic systemic diseases such as hypertension, diabetes mellitus, dyslipidaemia, neurological disorders, and allergy, as shown in Tables 4 and 5. The ocular symptoms of DES syndrome are classified into two groups, with the first being comprised of symptoms that are related to accommodation and that include blurred vision of near objects, blurry vision at a distance after using the computer, focusing difficulties between different distances, double vision, headaches, and neck and shoulder pain. The second is associated with dry eyes, burning sensation, irritation, discomfort, sensitivity to bright light, eyestrain, and headaches. ${ }^{1}$ Eyestrain and headaches are linked to binocular visual stress and accommodation, in addition to their connection to dryness. ${ }^{13,22}$

The most common symptom was neck and/or upper shoulder pain, followed by symptoms of accommodative dysfunction and to a lesser extent dry eyes. Prior to the lockdown, approximately 201 out of 250 respondents $(n=250)$ reported neck and/or shoulder pain; however, during the lockdown, this number nearly doubled to $390(n=489)$. This is in line with similar studies that found neck pain to be a common symptom among computer users, ranging from 19-70\%. ${ }^{7-9,23,24}$ Touch screen devices, according to Kargar et al., necessitate more hand and head movements, resulting in arm/neck pain. ${ }^{25}$ Another study found that $68 \%$ of participants experienced musculoskeletal pain as a result of using touch screens, with neck pain and upper shoulder pain reported at $84.6 \%$ and $65.4 \%$, respectively, due to unnatural sitting positions without adequate back support. ${ }^{26}$ Logaraj et al., who found that $60.7 \%$ of medical students reported neck pain as the most common symptom of DES, reported similar findings. ${ }^{19}$ Workers who used computers for more than 6 hours per day were more likely to report upper limb disorders, according to Blatter and Bongers. ${ }^{18}$ As an unexpected mechanism to explain musculoskeletal pain is the oculomotor accommodative, and vergences dysfunction due to DES; electromyography has shown that ciliary muscle contraction is associated with head and neck muscle activation. The stabilization of gaze by head and neck muscles during accommodation was studied by Richter et al. ${ }^{27}$ They noticed increased trapezius muscle activity in a dose-dependent manner when subjects were given different lenses in front of their eyes to stimulate the ciliary body. More head and neck muscle activity was observed, as accommodation was activated. ${ }^{27}$

As expected, blurred vision, both near and far, was the second most common symptom reported at baseline and during the lockdown. ${ }^{6,19,28,29}$ Rosenfield et al. (2011) attributed it to an incorrect accommodative response, as well as 
a failure to relax the ciliary body after the visual demand was completed. ${ }^{3}$ The use of smart phones and handheld devices, according to Jaiswal et al. (2019), cause symptoms that are similar to DES because they stimulate the accommodative facility, resulting in decreased amplitude when the eye is fatigued. Despite the fact that no definitive evidence has been found linking smartphones to accommodative facility dysfunction, additional research is required to uncover the actual impact of digital devices on long-term users. ${ }^{29}$

Figure 2 depicts the most commonly reported dry eye symptoms in this study population before and during lockdown are shown. The most common complaints were photophobia, burning sensation, and heaviness. Research studies provide similar findings, but the symptoms occur in a different order that is reflective of sampling and geographical variations. ${ }^{15,21,30,31}$

Dry eye symptoms might not be a legitimate component of DES, as dry eye disease may aggravate accommodative symptoms, especially in elderly men and women, as well as those who have ocular surface disease. However, DES affects people under the age of 18 who use digital devices; this necessitates the need to develop a more specific and precise definition of DES. ${ }^{32}$ Many patients who use dry eye treatments and increase their rate of blinking did not notice an improvement in their digital eye strain symptoms. Rosenfield and Jaiswal examined various factors that affect dry eye disease and its relation to DES in their reviews. ${ }^{3,29}$ They identified that various environmental factors, such as humidity, ambient lighting, fans, blinking rate, corneal exposure to air, gender, age, medications, systemic diseases, contact lenses, tear film volume, osmolality, and tear film composition, all affect the development of dry eye disease. Nonetheless, DES is still affecting normal people who are not at risk for dry eye disease. ${ }^{13,14,33,34}$

The major drawback of this study is that it is cross-sectional and uses convenient sampling methods. The participants may exaggerate or under exaggerate their symptoms due to the self-reporting nature of the survey.

\section{Conclusions}

The results of this online survey reveal the negative effect of COVID-19 on home confinement with eye problems due to the significant increase in usage time of digital devices, which is also indicative of a more sedentary lifestyle. The results concur with recent studies demonstrating that lockdown could dramatically increase digital eye strain that became a growing public health issue that affects people of all ages and occupational groups, posing a threat to their health and quality of life.

Indeed, individuals who spent more time on digital devices developed a new eye complaint four times more often than who did not. Females are at higher risk of having severe symptoms. As the first in Jordan, this study could explore the impact of lockdown on developing DES-related eye symptoms. The visual consequences of the COVID-19 outbreak, which placed a curfew on people all over the world, should attract more attention from researchers these days. Neglecting DES could cause the exacerbation of mild symptoms in people who had them before or the emergence of new complaints in people who never had them previously. The government of Jordan would develop public health interventions to mitigate the negative effects of Internet use on eye problems that have manifested during the COVID19 lockdown.

\section{Declarations}

Financial Disclosure: This research did not receive any specific grants from funding agencies in the public, commercial, or non-profit sectors. 
The data underlying this article will be shared on reasonable request with the corresponding author.

Conflict of interest: None declared

Ethical Approval: Institutional Review Board of the Al Balqa Applied University (BAU)

Consent to participate: All participants were consented by agreeing to fill in the questionnaire.

Consent for publication: All authors consent to publish this research

Acknowledgment: Authors are thankful to Dr.Yazan Gammoh PhD and Dr.Arfa Chokri PhD for their efforts and assistance with statistical analysis and cooperation.

Clinical Relevance: Repetitive use of digital devices without regular breaks has a detrimental effects on ocular health and quality of vision. Individuals with chronic eye problems and refractive errors are at higher risk of developing digital eye strain (DES). Correction of refractive errors, adopting healthy practices will reduce its risk.

\section{References}

1. Portello JK, Rosenfield M, Bababekova Y et al. Computer-related visual symptoms in office workers: Visual symptoms in office workers. Ophthalmic Physiol Opt. 2012;32(5):375-382. doi:10.1111/j.14751313.2012.00925.x

2. Sheedy JE. The bottom line on fixing computer-related vision and eye problems. J Am Optom Assoc. 1996;67(9):512-517.

3. Rosenfield M. Computer vision syndrome: a review of ocular causes and potential treatments: Computer vision syndrome. Ophthalmic Physiol Opt. 2011;31(5):502-515. doi:10.1111/j.1475-1313.2011.00834.x

4. Heus P, Verbeek JH, Tikka C. Optical correction of refractive error for preventing and treating eye symptoms in computer users. Cochrane Work Group, ed. Cochrane Database Syst Rev. Published online April 10, 2018. doi:10.1002/14651858.CD009877.pub2

5. American Optometric Association. Computer vision syndrome. 2017. https://www.aoa.org/patients-andpublic/caring-for-your-vision/protecting-your-vision/computer-vision-syndrome?sso=y.Acessed March 12, 2021

6. Blehm C, Vishnu S, Khattak A et al. Computer Vision Syndrome: A Review. Surv Ophthalmol. 2005;50(3):253-262. doi:10.1016/j.survophthal.2005.02.008

7. Oha K, Animägi L, Pääsuke M et al. Individual and work-related risk factors for musculoskeletal pain: a crosssectional study among Estonian computer users. BMC Musculoskelet Disord. 2014;15:181. doi:10.1186/14712474-15-181

8. Woods V. Musculoskeletal disorders and visual strain in intensive data processing workers. Occup Med Oxf Engl. 2005;55(2):121-127. doi:10.1093/occmed/kqi029

9. Harcombe H, McBride D, Derrett S et al. Prevalence and impact of musculoskeletal disorders in New Zealand nurses, postal workers, and office workers. Aust N Z J Public Health. 2009;33(5):437-441. doi:10.1111/j.17536405.2009.00425.x

10. Şimşek C, Doğru M, Kojima T et al. Current Management and Treatment of Dry Eye Disease. Turk J Ophthalmol. 2018;48(6):309-313. Doi: 10.4274/tjo.69320

11. Facebook Users in Jordan Https://Napoleoncat.Com/Stats/Facebook-Users-in-Jordan/2020/04.Accessed March 21,2021 
12. Ranasinghe $P$, Wathurapatha WS, Perera $Y S$, et al. Computer vision syndrome among computer office workers in a developing country: evaluation of prevalence and risk factors. BMC Res Notes. 2016;9(1):150. doi:10.1186/s13104-016-1962-1

13. Sheppard AL, Wolffsohn JS. Digital eye strain: prevalence, measurement, and amelioration. BMJ Open Ophthalmol. 2018;3(1):e000146. doi:10.1136/bmjophth-2018-000146

14. Shantakumari N, Eldeeb R, Sreedharan J, et al. Computer use and vision-related problems among university students in Ajman, United Arab emirates. Ann Med Health Sci Res. 2014;4(2):258-263. doi:10.4103/21419248.129058

15. Touma Sawaya R, El Meski N, Saba J, et al. Asthenopia among university students: The eye of the digital generation. J Fam Med Prim Care. 2020;9(8):3921. doi:10.4103/jfmpc.jfmpc_340_20

16. Common Sense Media https://www.commonsensemedia.org/about-us/news/press-releases/new-report-parentsspend-more-than-nine-hours-a-day-with-screen-media.Accessed March 12, 2021

17. 2019 THE COMMON SENSE CENSUS: Media Use By Tweens and Teens Https://Www.Commonsensemedia.Org/Sites/Default/Files/Uploads/Research/2019-Census-8-to-18-KeyFindings-Updated.Pdf. Accessed March 12, 2021. https://www.commonsensemedia.org/sites/default/files/uploads/research/2019-census-8-to-18-key-findingsupdated.pdf

18. Blatter BM, Bongers PM. Duration of computer use and mouse use in relation to musculoskeletal disorders of the neck or upper limb. Int J Ind Ergon. 2002;30(4-5):295-306. doi:10.1016/S0169-8141(02)00132-4

19. Logaraj M, Madhupriya V, Hegde S. Computer vision syndrome and associated factors among medical and engineering students in chennai. Ann Med Health Sci Res. 2014;4(2):179-185. doi:10.4103/2141-9248.129028

20. Lemma MG, Beyene KG, Tiruneh MA. Computer Vision Syndrome and Associated Factors Among Secretaries Working in Ministry Offices in Addis Ababa, Ethiopia. Clin Optom. 2020;Volume 12:213-222. doi:10.2147/OPTO.S284934

21. Reddy SC, Low C, Lim Y, et al. Computer vision syndrome: a study of knowledge and practices in university students. Nepal J Ophthalmol. 2013;5(2):161-168. doi:10.3126/nepjoph.v5i2.8707

22. Sheedy JE, Hayes J, Engle J. Is all Asthenopia the Same?: Optom Vis Sci. 2003;80(11):732-739. doi:10.1097/00006324-200311000-00008

23. Janwantanakul P, Pensri P, Jiamjarasrangsri V et al. Prevalence of self-reported musculoskeletal symptoms among office workers. Occup Med Oxf Engl. 2008;58(6):436-438. doi:10.1093/occmed/kqn072

24. Mowatt L, Gordon C, Santosh ABR, Jones T. Computer vision syndrome and ergonomic practices among undergraduate university students. Int J Clin Pract. 2018;72(1):e13035. doi:10.1111/ijcp.13035

25. Kargar N, Choobineh AR, Razeghi M, et al. Posture and discomfort assessment in computer users while using touch screen device as compared with mouse-keyboard and touch pad keyboard. Work. 2018;59(3):341-349. doi:10.3233/WOR-182685

26. Blair B, Gama M, Toberman M. Prevalence and Risk Factors for Neck and Shoulder Musculoskeletal Symptoms in Users of Touch-Screen Tablet Computers Blair, Betina; Gama, Mariana; and Toberman, Marissa, "Prevalence and Risk Factors for Neck and Shoulder Musculoskeletal Symptoms in Users of Touch-Screen Tablet Computers" (2015). UNLV Theses, Dissertations, Professional Papers, and Capstones. 2320. https://digitalscholarship.unlv.edu/thesesdissertations/2320. :45.

27. Richter HO, Bänziger T, Abdi S, et al. Stabilization of gaze: A relationship between ciliary muscle contraction and trapezius muscle activity. Vision Res. 2010;50(23):2559-2569. doi:10.1016/j.visres.2010.08.021

Page 9/20 
28. Gowrisankaran S, Sheedy JE. Computer vision syndrome: A review. Albin TJ, ed. Work. 2015;52(2):303-314. doi:10.3233/WOR-152162

29. Jaiswal S, Asper L, Long J, et al. Ocular and visual discomfort associated with smartphones, tablets, and computers: what we do and do not know. Clin Exp Optom. 2019;102(5):463-477. doi:10.1111/cxo.12851

30. Loh K, Redd S. Understanding and preventing computer vision syndrome. Malays Fam Physician J Acad Fam Physicians Malays. 2008;3(3):128-130.

31. Alshamrani A, Almousa A, Almulhim A, et al. Prevalence and risk factors of dry eye symptoms in a Saudi Arabian population. Middle East Afr J Ophthalmol. 2017;24(2):67. doi:10.4103/meajo.MEAJO_281_16

32. Junghans BM, Azizoglu S, Crewther SG. Unexpectedly high prevalence of asthenopia in Australian school children identified by the CISS survey tool. BMC Ophthalmol. 2020;20(1):408. doi:10.1186/s12886-020-01642-3

33. Mylona I, Deres ES, Dere G-DS, et al. The Impact of Internet and Videogaming Addiction on Adolescent Vision: A Review of the Literature. Front Public Health. 2020;8:63. doi:10.3389/fpubh.2020.00063

34. Randolph SA. Computer Vision Syndrome. Workplace Health Saf. 2017;65(7):328-328. doi:10.1177/2165079917712727

\section{Tables}

Table 1: Characteristics of Participants $(n=1,460)$ 


\begin{tabular}{|c|c|c|c|}
\hline Variable & Category & No. & Percentage \\
\hline \multirow{2}{*}{ Gender } & Male & 869 & $59.5 \%$ \\
\hline & Female & 591 & $40.5 \%$ \\
\hline \multirow{4}{*}{ Age groups (years) } & $5-17$ & 39 & $2.7 \%$ \\
\hline & $18-29$ & 427 & $29.2 \%$ \\
\hline & $30-49$ & 699 & $47.9 \%$ \\
\hline & $50-99$ & 295 & $20.2 \%$ \\
\hline \multirow{7}{*}{ Occupation } & School student & 44 & $3 \%$ \\
\hline & University student & 242 & $16.6 \%$ \\
\hline & Manual worker & 109 & $7.5 \%$ \\
\hline & Health care provider & 190 & $13 \%$ \\
\hline & Desk job & 287 & $19.7 \%$ \\
\hline & Academic & 174 & $11.9 \%$ \\
\hline & Retired or household & 414 & $28.4 \%$ \\
\hline Chronic systemic diseases & $\begin{array}{l}\text { Yes } \\
\text { No }\end{array}$ & $\begin{array}{l}305 \\
1155\end{array}$ & $\begin{array}{l}20.9 \% \\
79.1 \%\end{array}$ \\
\hline $\begin{array}{l}\text { Baseline Time using digital } \\
\text { devices (hours/day) }\end{array}$ & $\begin{array}{l}\text { Yes } \\
\text { No } \\
1-2 \\
3-5 \\
6-8 \\
>8\end{array}$ & $\begin{array}{l}335 \\
1125 \\
282 \\
616 \\
290 \\
272\end{array}$ & $\begin{array}{l}22.9 \% \\
77.1 \% \\
19.3 \% \\
42.2 \% \\
19.9 \% \\
18.6 \%\end{array}$ \\
\hline $\begin{array}{l}\text { Increased time during } \\
\text { corona (hours/day), } n= \\
957\end{array}$ & $\begin{array}{l}<1 \\
1-2 \\
3-4 \\
>4 \\
\end{array}$ & $\begin{array}{l}68 \\
307 \\
263 \\
319 \\
\end{array}$ & $\begin{array}{l}7.1 \% \\
32.1 \% \\
27.5 \% \\
33.3 \% \\
\end{array}$ \\
\hline
\end{tabular}

Table 2: Prevalence of Symptoms at Baseline and During Lockdown 


\begin{tabular}{|c|c|c|c|c|c|c|c|c|}
\hline \multirow[t]{3}{*}{ Symptoms } & \multicolumn{4}{|c|}{ Symptoms at baseline } & \multicolumn{4}{|c|}{ Symptoms during lockdown } \\
\hline & No & Sometimes & Always & Total & No & Sometimes & Always & Total \\
\hline & $n(\%)$ & $n(\%)$ & $n(\%)$ & \# & $n(\%)$ & $n(\%)$ & $n(\%)$ & \# \\
\hline \multicolumn{9}{|c|}{ I. Accommodative symptoms } \\
\hline Neck pain & $\begin{array}{l}49 \\
(19.6)\end{array}$ & $135(54)$ & $\begin{array}{l}66 \\
(26.4)\end{array}$ & 250 & $99(20.2)$ & $224(45.8)$ & $\begin{array}{l}166 \\
(33.9)\end{array}$ & 489 \\
\hline $\begin{array}{l}\text { Blurred vision at a } \\
\text { distance }\end{array}$ & $\begin{array}{l}66 \\
(25.7)\end{array}$ & $171(66.5)$ & $\begin{array}{l}20 \\
(7.8)\end{array}$ & 257 & $\begin{array}{l}117 \\
(25.7)\end{array}$ & $277(60.9)$ & $\begin{array}{l}61 \\
(13.4)\end{array}$ & 455 \\
\hline Headache & $\begin{array}{l}61 \\
(24.3)\end{array}$ & $146(58.2)$ & $\begin{array}{l}44 \\
(17.5)\end{array}$ & 251 & $\begin{array}{l}121 \\
(25.4)\end{array}$ & 249 (51.9) & $\begin{array}{l}109 \\
(22.7)\end{array}$ & 480 \\
\hline $\begin{array}{l}\text { Blurred vision of } \\
\text { near objects }\end{array}$ & $\begin{array}{l}67 \\
(26.5)\end{array}$ & $131(51.8)$ & $\begin{array}{l}55 \\
(21.7)\end{array}$ & 253 & $\begin{array}{l}157 \\
(33.2)\end{array}$ & $193(40.8)$ & $\begin{array}{l}123 \\
(26.0)\end{array}$ & 473 \\
\hline Eye strain & $\begin{array}{l}88 \\
(36.1)\end{array}$ & $131(53.7)$ & $\begin{array}{l}25 \\
(10.2)\end{array}$ & 244 & $\begin{array}{l}187 \\
(41.2)\end{array}$ & $228(50.2)$ & $\begin{array}{l}39 \\
(8.6)\end{array}$ & 454 \\
\hline Double vision & $\begin{array}{l}161 \\
(66.8)\end{array}$ & $67(27.8)$ & $\begin{array}{l}14 \\
(5.4)\end{array}$ & 242 & $\begin{array}{l}320 \\
(69.7)\end{array}$ & $110(24.0)$ & $\begin{array}{l}29 \\
(6.3)\end{array}$ & 459 \\
\hline \multicolumn{9}{|l|}{ II. Dry eye symptoms } \\
\hline Burning sensation & $\begin{array}{l}66 \\
(26.1)\end{array}$ & $163(64.4)$ & $\begin{array}{l}24 \\
(9.9)\end{array}$ & 253 & $\begin{array}{l}101 \\
(22.1)\end{array}$ & $302(65.9)$ & $\begin{array}{l}55 \\
(12.0)\end{array}$ & 458 \\
\hline Photophobia & $\begin{array}{l}60 \\
(24.8)\end{array}$ & $142(58.7)$ & $\begin{array}{l}40 \\
(16.5)\end{array}$ & 242 & $\begin{array}{l}139 \\
(29.8)\end{array}$ & $230(49.3)$ & $\begin{array}{l}98 \\
(21.0)\end{array}$ & 457 \\
\hline Heaviness of eyelids & $\begin{array}{l}80 \\
(32.27)\end{array}$ & $137(55.9)$ & $\begin{array}{l}28 \\
(11.4)\end{array}$ & 245 & $\begin{array}{l}174 \\
(39.0)\end{array}$ & $123(45.5)$ & $\begin{array}{l}69 \\
(15.5)\end{array}$ & 446 \\
\hline Lacrimation & $\begin{array}{l}89 \\
(36.5)\end{array}$ & 134 (54.9) & $\begin{array}{l}21 \\
(8.6)\end{array}$ & 244 & $\begin{array}{l}171 \\
(37.8)\end{array}$ & 233 (51.5) & $\begin{array}{l}48 \\
(10.6)\end{array}$ & 452 \\
\hline FB sensation & $\begin{array}{l}124 \\
(50.6)\end{array}$ & 106 (43.3) & $\begin{array}{l}15 \\
(6.1)\end{array}$ & 245 & $239(52.4)$ & 181 (39.7) & $\begin{array}{l}36 \\
(7.9)\end{array}$ & 456 \\
\hline Eye redness & $\begin{array}{l}131 \\
(53.3)\end{array}$ & $111(45.1)$ & $4(1.6)$ & 246 & $\begin{array}{l}231 \\
(52.3)\end{array}$ & 178 (40.3) & $\begin{array}{l}33 \\
(7.5)\end{array}$ & 442 \\
\hline
\end{tabular}

Table 3: Association of Before and During Lockdown Symptoms of DES $(n=242)$ 


\begin{tabular}{|c|c|c|c|c|c|c|c|c|}
\hline \multirow[b]{2}{*}{ Symptom } & \multicolumn{3}{|c|}{ Before lockdown } & \multicolumn{3}{|c|}{ During lockdown } & \multirow[b]{2}{*}{$x^{2 a}$} & \multirow[b]{2}{*}{$\begin{array}{l}P \\
\text { value }\end{array}$} \\
\hline & $\begin{array}{l}\text { No } \\
n(\%)\end{array}$ & $\begin{array}{l}\text { Sometimes } \\
\mathrm{n}(\%)\end{array}$ & $\begin{array}{l}\text { Always } \\
\mathrm{n}(\%)\end{array}$ & $\begin{array}{l}\text { No } \\
\mathrm{n}(\%)\end{array}$ & $\begin{array}{l}\text { Sometimes } \\
\mathrm{n}(\%)\end{array}$ & $\begin{array}{l}\text { Always } \\
\mathrm{n}(\%)\end{array}$ & & \\
\hline $\begin{array}{l}\text { Blurred vision } \\
\text { at a distance }\end{array}$ & $60(24.8)$ & $158(65.3)$ & $24(9.9)$ & $46(19)$ & $146(60.3)$ & $50(20.7)$ & 144.47 & 0.000 \\
\hline $\begin{array}{l}\text { Burning } \\
\text { sensation }\end{array}$ & $61(25.2)$ & $157(64.9)$ & $24(9.9)$ & $51(21.1)$ & $162(66.9)$ & $29(12)$ & 151.13 & 0.000 \\
\hline Eye redness & $134(55.4)$ & $104(43)$ & $4(1.6)$ & $122(50.4)$ & $103(42.5)$ & $17(7.1)$ & 194.17 & 0.000 \\
\hline Lacrimation & $86(35.5)$ & $136(56.2)$ & $20(8.3)$ & $75(31.0)$ & $141(58.3)$ & $26(10.7)$ & 116.91 & 0.000 \\
\hline $\begin{array}{l}\text { Heaviness of } \\
\text { eyelids }\end{array}$ & $90(37.2)$ & $122(50.4)$ & $30(12.4)$ & $73(30.1)$ & $129(53.3)$ & $40(16.6)$ & 139.42 & 0.000 \\
\hline $\begin{array}{l}\text { Foreign body } \\
\text { sensation }\end{array}$ & $126(52.1)$ & $102(42.1)$ & $14(5.8)$ & $121(50)$ & $102(42.1)$ & $19(7.9)$ & 183.67 & 0.000 \\
\hline $\begin{array}{l}\text { Blurred vision } \\
\text { of near }\end{array}$ & $80(33)$ & $111(45.9)$ & $51(21.1)$ & $65(26.9)$ & $112(46.2)$ & $65(26.9)$ & 135.17 & 0.000 \\
\hline Double vision & 163(67.3) & $66(27.3)$ & $13(5.4)$ & $150(62)$ & $74(30.6)$ & $18(7.4)$ & 163.57 & 0.000 \\
\hline Eye strain & $88(36.4)$ & $130(53.7)$ & $24(9.9)$ & $85(35.1)$ & $129(53.3)$ & $28(11.6)$ & 128.33 & 0.000 \\
\hline Headache & $61(25.2)$ & $141(58.3)$ & $40(16.5)$ & 49 (19.5) & $135(55.6)$ & $58(24.9)$ & 190.17 & 0.000 \\
\hline Photophobia & $60(24.8)$ & $142(58.7)$ & $40(16.5)$ & $51(21.1)$ & $128(52.9)$ & $63(26)$ & 174.11 & 0.000 \\
\hline $\begin{array}{l}\text { Neck/Shoulder } \\
\text { pain }\end{array}$ & $49(20.2)$ & $129(53.4)$ & $64(26.4)$ & 40 (16.5) & $116(48)$ & $86(35.5)$ & 201.61 & 0.000 \\
\hline
\end{tabular}

$\mathbf{a}=$ Chi Square

Table 4: Association of Development of New Eye Complaints During Lockdown with Demographic Factors and Eye Factors of Participants 


\section{Factor analyzed}

\begin{tabular}{ll} 
No & Yes \\
\hline$n(\%)$ & $n(\%)$
\end{tabular}

Gender

Female

Male

Age(in years)

$5-17$

$18-29$

$30-49$

$50-99$

\section{Occupation}

School student

University student

Manual worker

Health care provider

Desk job

Academic

Retired

Chronic systemic disease

Yes

(22.2)

9 (20)

35 (78)

$3.620 .001^{*}$

105 (43) $137(57)$

$46(42) \quad 63(58)$

$60(32)$

130 (68)

$83(29) \quad 204(71)$

63 (43)

63 (57)

161 (39)

$161(61)$

No

188
$(35.7)$

(35.7)

$2.83 \quad 0.037$ *

$9.20 \quad 0.002^{*}$

$186(13) \quad 405(66)$

341 (39) $528(61)$

170 (12) $257(18)$

247 (35) $\quad 452$ (31)

103 (35) $192(66)$

Time using digital devices before lockdown (Baseline) in hours/day

\begin{tabular}{|c|c|c|c|c|}
\hline $1-2$ & $94(6)$ & $188(13)$ & & \\
\hline $3-5$ & $217(15)$ & 399 (27) & & \\
\hline $6-8$ & $106(7)$ & $184(13)$ & & \\
\hline$>8$ & $110(8)$ & $162(11)$ & & \\
\hline \multicolumn{5}{|c|}{ Time increase using digital devices } \\
\hline \multirow{2}{*}{$\begin{array}{l}\text { Yes } \\
\text { No }\end{array}$} & $\begin{array}{l}247 \\
(25.6)\end{array}$ & $\begin{array}{l}710 \\
(74.4)\end{array}$ & \multirow[t]{2}{*}{127.41} & \multirow[t]{2}{*}{$0.000 *$} \\
\hline & $\begin{array}{l}280 \\
(55.6)\end{array}$ & $\begin{array}{l}223 \\
(44.4)\end{array}$ & & \\
\hline
\end{tabular}

Page $14 / 20$ 


\begin{tabular}{|c|c|c|c|c|}
\hline \multicolumn{5}{|c|}{ Time using digital devices during lockdown (in hours/day) } \\
\hline$<1$ & $10(0.6)$ & $58(4)$ & 30.833 & $0.000^{*}$ \\
\hline $1-2$ & $53(4)$ & $254(17)$ & & \\
\hline $3-4$ & $72(5)$ & $191(13)$ & & \\
\hline$>4$ & $112(8)$ & $207(14)$ & & \\
\hline
\end{tabular}

* = statistically significant

Table 5: Association of increased Eye Symptoms Severity During COVID-19 Lockdown and Demographic and Eye Factors of Participants 


\begin{tabular}{|c|c|c|c|c|c|c|}
\hline \multirow[t]{2}{*}{ Factors analyzed } & \multicolumn{2}{|l|}{ Yes } & \multicolumn{3}{|l|}{ No } & \multirow[b]{2}{*}{$P$ value } \\
\hline & $\mathrm{N}$ & $\%$ & $\mathrm{~N}$ & $\%$ & $x^{2}$ & \\
\hline \multicolumn{5}{|l|}{ Gender } & \multirow{3}{*}{5.374} & \multirow{3}{*}{0.020 * } \\
\hline Female & 190 & $13 \%$ & 151 & $10 \%$ & & \\
\hline Male & 84 & $6 \%$ & 102 & $7 \%$ & & \\
\hline \multicolumn{5}{|l|}{ Age groups } & \multirow{5}{*}{1.460} & \multirow{5}{*}{0.692} \\
\hline $5-17$ & 3 & $0.2 \%$ & 4 & $0.3 \%$ & & \\
\hline $18-29$ & 85 & $6 \%$ & 85 & $6 \%$ & & \\
\hline $30-49$ & 135 & $9 \%$ & 112 & $8 \%$ & & \\
\hline $50-99$ & 51 & $3.5 \%$ & 52 & $3.5 \%$ & & \\
\hline \multicolumn{5}{|l|}{ Occupation } & \multirow{8}{*}{5.098} & \multirow{8}{*}{0.531} \\
\hline School student & 3 & $0.2 \%$ & 6 & $0.04 \%$ & & \\
\hline University student & 51 & $3.5 \%$ & 54 & $3.7 \%$ & & \\
\hline Manual worker & 21 & $1.4 \%$ & 25 & $2 \%$ & & \\
\hline Health care provider & 34 & $2.3 \%$ & 26 & $2 \%$ & & \\
\hline Desk job & 40 & $2.7 \%$ & 43 & $3 \%$ & & \\
\hline Academic & 37 & $2.5 \%$ & 26 & $2 \%$ & & \\
\hline Retired & 88 & $6 \%$ & 73 & $5 \%$ & & \\
\hline \multicolumn{5}{|c|}{ Time increased using digital devices in hours/day } & \multirow{5}{*}{30.833} & \multirow{5}{*}{0.000 * } \\
\hline Less $1 \mathrm{hrs}$ & 10 & $0.6 \%$ & 58 & $4 \%$ & & \\
\hline $1-2 \mathrm{hrs}$ & 53 & $4 \%$ & 254 & $17 \%$ & & \\
\hline $3-4 \mathrm{hrs}$ & 72 & $5 \%$ & 191 & $13 \%$ & & \\
\hline More than 4 hrs & 112 & $8 \%$ & 207 & $14 \%$ & & \\
\hline \multicolumn{5}{|c|}{ Chronic systemic diseases } & \multirow{3}{*}{12.45} & \multirow{3}{*}{0.000 * } \\
\hline Yes & 67 & $57.3 \%$ & 50 & $42.7 \%$ & & \\
\hline No & 88 & $69.9 \%$ & 39 & $30.1 \%$ & & \\
\hline \multicolumn{5}{|c|}{ Time increase using digital devices per day } & \multirow{3}{*}{429.259} & \multirow{3}{*}{0.000 * } \\
\hline Yes & 27 & $1.8 \%$ & 253 & $17.3 \%$ & & \\
\hline No & 247 & $17 \%$ & 0 & $0 \%$ & & \\
\hline \multicolumn{5}{|l|}{ Taking regular breaks } & \multirow{3}{*}{.025} & \multirow{3}{*}{.988} \\
\hline No & 15 & $62.5 \%$ & 9 & $37.5 \%$ & & \\
\hline Sometimes & 58 & $60.4 \%$ & 33 & $39.6 \%$ & & \\
\hline
\end{tabular}


$25 \quad 62.5 \% \quad 15 \quad 37.5 \%$

Chronic eye complaints

Yes

$100 \quad 0.7 \% \quad 57 \quad 4 \%$

No

$\begin{array}{llllll}174 & 12 \% & 196 & 13.4 \% & 12.27 & 0.000 \text { * }\end{array}$

* = Statistically significant

Table 6: Factors Associated with Emergence of New Eye Complaints and Increased Severity of Current Eye Complaints by Logistic Regression 


\begin{tabular}{|c|c|c|c|c|c|}
\hline \multirow[b]{2}{*}{ Factors } & \multirow[b]{2}{*}{ Categories } & \multicolumn{2}{|c|}{$\begin{array}{l}\text { Model 1: New complaint } \\
\text { development }\end{array}$} & \multicolumn{2}{|c|}{$\begin{array}{l}\text { Model 2: Increased } \\
\text { severity }\end{array}$} \\
\hline & & OR $(95 \% \mathrm{Cl})$ & $\begin{array}{l}\mathrm{p}- \\
\text { Value }\end{array}$ & OR $(95 \% \mathrm{Cl})$ & Value \\
\hline \multirow[t]{4}{*}{ Age (years) } & $5-17$ & 1 & & 1 & \\
\hline & $18-29$ & $\begin{array}{l}3.23(0.48- \\
21.6)\end{array}$ & 0.226 & $\begin{array}{l}0.54(0.03- \\
9.43)\end{array}$ & 0.676 \\
\hline & $30-49$ & $\begin{array}{l}3.33(0.49- \\
22.7)\end{array}$ & 0.219 & $\begin{array}{l}0.58(0.33- \\
10.08)\end{array}$ & 0.706 \\
\hline & $50+$ & $\begin{array}{l}2.99(0.22- \\
0.67)\end{array}$ & 0.269 & $\begin{array}{l}0.43(0.02- \\
7.58)\end{array}$ & 0.561 \\
\hline \multirow[t]{2}{*}{ Gender } & Female & 1 & & 1 & \\
\hline & Male & $\begin{array}{l}1.30(0.99- \\
1.69)^{(}\end{array}$ & 0.051 & $\begin{array}{l}1.78(1.28- \\
2.50)\end{array}$ & $0.001^{*}$ \\
\hline \multirow[t]{7}{*}{ Occupation } & $\begin{array}{l}\text { School } \\
\text { students }\end{array}$ & 1 & & 1 & \\
\hline & $\begin{array}{l}\text { University } \\
\text { students }\end{array}$ & $\begin{array}{l}1.47(0.25- \\
8.06)\end{array}$ & 0.695 & $\begin{array}{l}4.73(0.28- \\
79.88)\end{array}$ & 0.281 \\
\hline & $\begin{array}{l}\text { Manual } \\
\text { worker }\end{array}$ & $\begin{array}{l}1.42(0.24- \\
8.45)\end{array}$ & 0.579 & $\begin{array}{l}5.60(0.31- \\
97.52)\end{array}$ & 0.238 \\
\hline & $\begin{array}{l}\text { Healthcare } \\
\text { provider }\end{array}$ & $\begin{array}{l}0.93(0.16- \\
5.34)\end{array}$ & 0.929 & $\begin{array}{l}4.16(0.24- \\
70.70)\end{array}$ & 0.324 \\
\hline & Desk job & $\begin{array}{l}0.74(0.13-4- \\
27)\end{array}$ & 0.737 & $\begin{array}{l}3.88(0.23- \\
65.91)\end{array}$ & 0.349 \\
\hline & Academic & $\begin{array}{l}1.06(0.18- \\
6.15)\end{array}$ & 0.951 & $\begin{array}{l}4.52(0.26- \\
77.21)\end{array}$ & 0.297 \\
\hline & $\begin{array}{l}\text { Retired or } \\
\text { household }\end{array}$ & $\begin{array}{l}0.96(0.17- \\
5.48)\end{array}$ & 0.962 & $\begin{array}{l}6.09(0.37- \\
101.5)\end{array}$ & 0.369 \\
\hline \multirow[t]{2}{*}{ Chronic systemic disease } & No & 1 & & 1 & \\
\hline & Yes & $\begin{array}{l}1.18(0.87- \\
1.59)^{-}\end{array}$ & 0.293 & $\begin{array}{l}1.27(0.88- \\
1.85)^{(0-}\end{array}$ & 0.204 \\
\hline \multirow[t]{2}{*}{ Chronic eye disease } & No & 1 & & 1 & \\
\hline & Yes & $\begin{array}{l}2.64(1.42- \\
4.88)^{-}\end{array}$ & 0.002 & $\begin{array}{l}2.63(1.34- \\
5.19)\end{array}$ & $0.005^{\star}$ \\
\hline \multirow{2}{*}{$\begin{array}{l}\text { Did your time using digital devices } \\
\text { increase during lockdown? }\end{array}$} & No & 1 & & 1 & \\
\hline & Yes & $\begin{array}{l}3.56(1.87- \\
5.24)\end{array}$ & 0.019 & $\begin{array}{l}5.16(3.73- \\
7.92)\end{array}$ & $0.000^{*}$ \\
\hline \multirow[t]{3}{*}{ How much time increased } & No & 1 & & 1 & \\
\hline & $1-2 \mathrm{~h}$ & $\begin{array}{l}0.20(0.14- \\
0.29)\end{array}$ & 0.000 & $\begin{array}{l}3.43(2.18- \\
5.41)\end{array}$ & $0.000^{*}$ \\
\hline & $3-4 \mathrm{~h}$ & $\begin{array}{l}0.35(0.25- \\
0.48)\end{array}$ & 0.000 & $\begin{array}{l}6.23(4.03- \\
9.83)\end{array}$ & $0.000^{*}$ \\
\hline
\end{tabular}




\begin{tabular}{|c|c|c|c|c|c|}
\hline & $5+h$ & $\begin{array}{l}0.46(0.34- \\
0.62)\end{array}$ & 0.000 & $\begin{array}{l}9.06(5.92- \\
13.87)\end{array}$ & $0.000^{*}$ \\
\hline \multirow{3}{*}{$\begin{array}{l}\text { Do you take regular breaks while using } \\
\text { digital devices? }\end{array}$} & No & 1 & & 1 & \\
\hline & Sometimes & $\begin{array}{l}0.74(0.38- \\
1.45)\end{array}$ & 0.385 & $\begin{array}{l}0.98(0.47- \\
2.05)\end{array}$ & 0.955 \\
\hline & Always & $\begin{array}{l}0.49(0.23- \\
1.02)\end{array}$ & 0.058 & $\begin{array}{l}0.79(0.35- \\
1.81)\end{array}$ & 0.582 \\
\hline
\end{tabular}

*= statistically significant

\section{Figures}

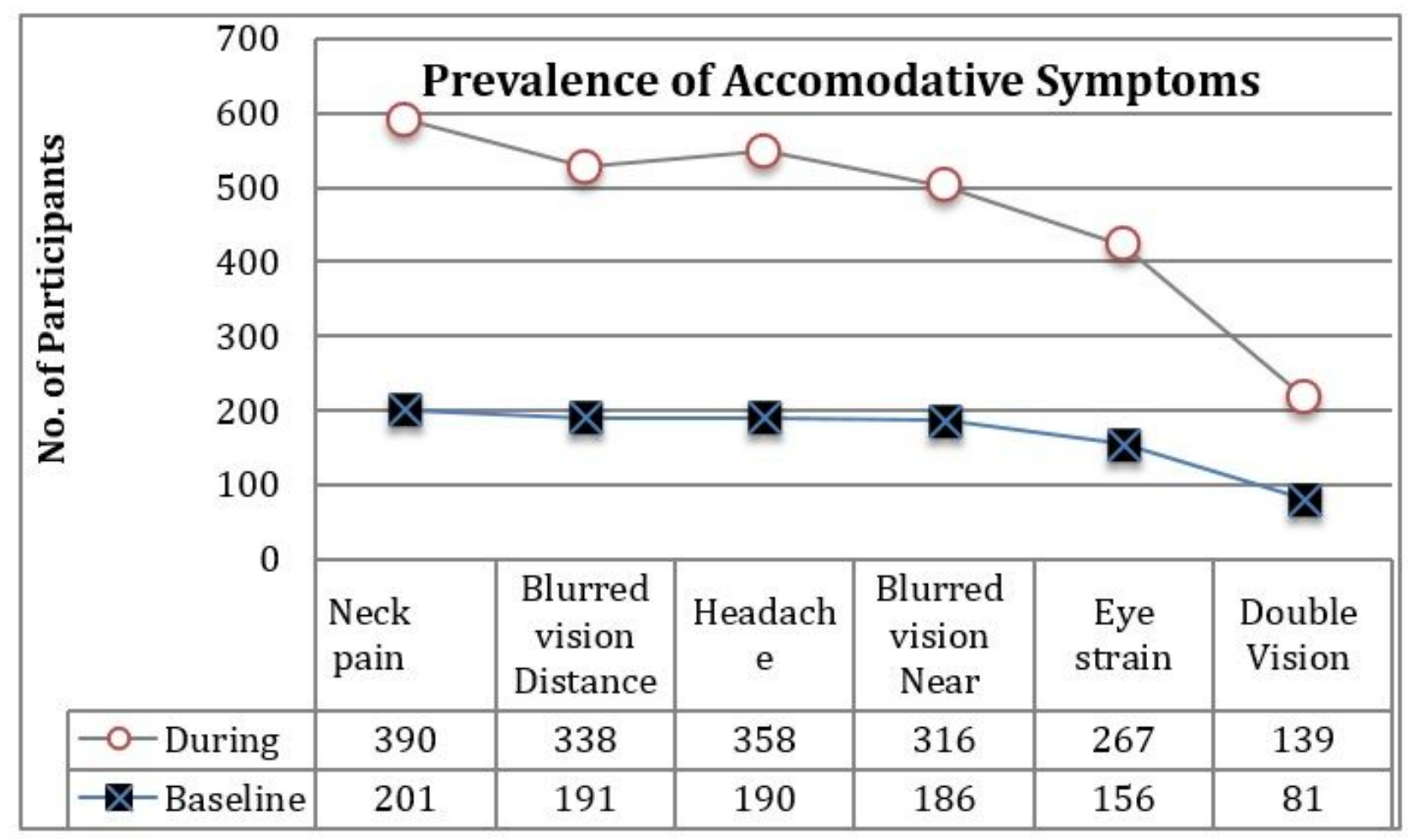

Figure 1

Prevalence of accommodative symptoms before and during lockdown 


\section{Prevalence of Dry Eye Symptoms}

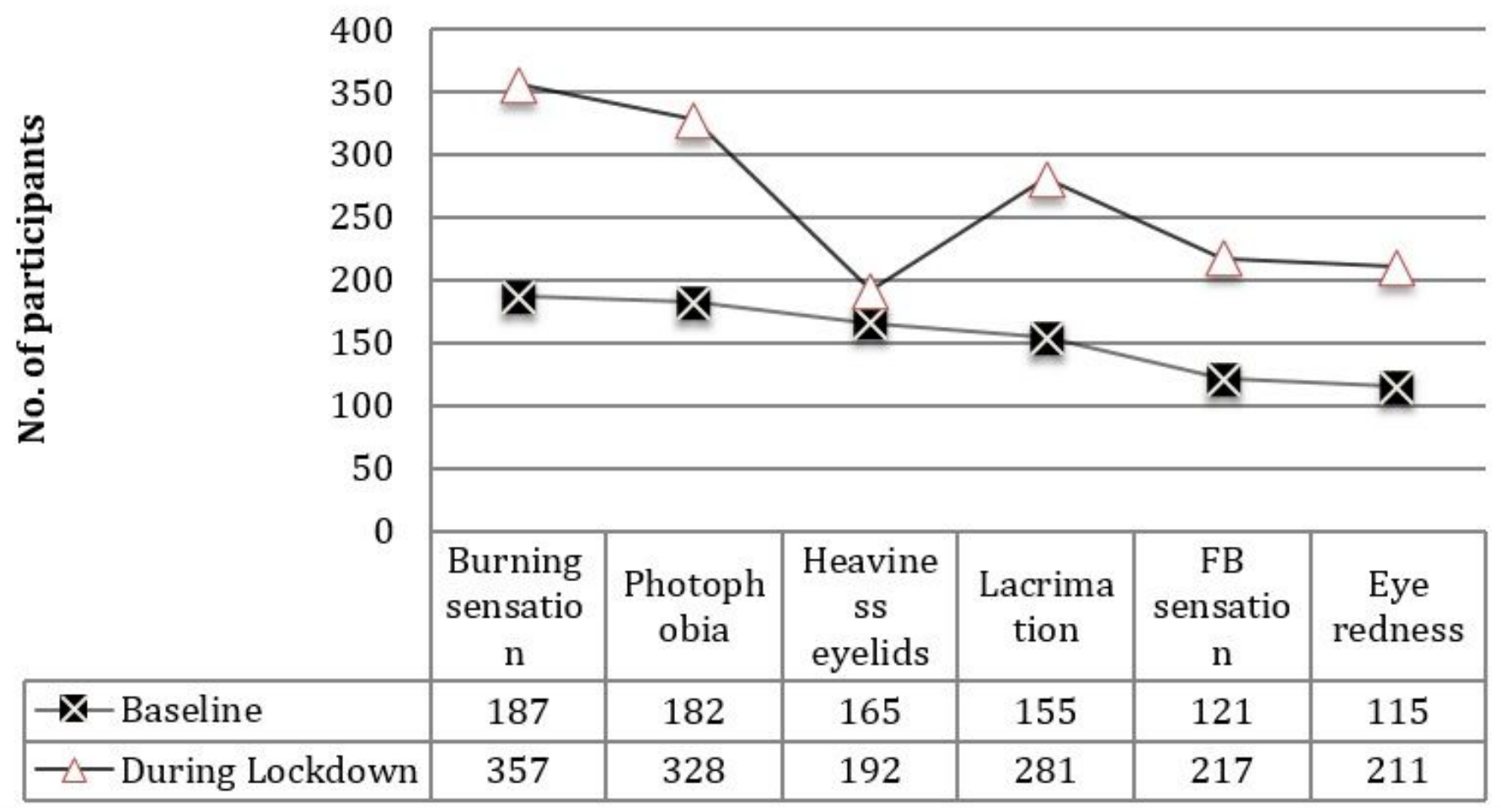

Figure 2

Prevalence of dry eye symptoms before and during lockdown

\section{Supplementary Files}

This is a list of supplementary files associated with this preprint. Click to download.

- AppendixThestudyquestionnaire.docx 